\title{
Risk Factors for Regional and Systemic Metastases in Patients with Sentinel Lymph Node-negative Melanoma
}

\author{
MICHAEL ERDMANN ${ }^{1}$, DOMINIC SIGLER ${ }^{2}$, UGUR USLU ${ }^{1}$, JONAS GÖHL ${ }^{2}$, \\ ROBERT GRÜTZMANN ${ }^{2}$, GEROLD SCHULER ${ }^{1}$ and VERA SCHELLERER ${ }^{2}$ \\ ${ }^{1}$ Department of Dermatology, University Hospital Erlangen, \\ Friedrich Alexander University Erlangen-Nürnberg (FAU), Erlangen, Germany; \\ ${ }^{2}$ Department of Surgery, University Hospital Erlangen, \\ Friedrich Alexander University Erlangen-Nürnberg (FAU), Erlangen, Germany
}

\begin{abstract}
Background: Sentinel lymph node status is a strong prognostic factor in melanoma. However, up to $21 \%$ of sentinel lymph node-negative patients develop locoregional and distant metastases during follow-up. Aim: To analyze risk factors for locoregional and distant metastasis in patients with sentinel lymph node-negative melanoma. Patients and Methods: A total of 545 patients underwent sentinel lymph node biopsy (SNB) between 2005 and 2013 at our hospital. Data for 449 patients with a negative SNB were analyzed regarding risk factors and development of metastases. Followup was performed until 2016. Results: A total of 72 SNBnegative patients developed metastases, including 25 (34.7\%) distant and 47 (63.3\%) locoregional metastases. Locoregional metastases occurred earlier compared to distant metastases (with a mean of 24.2 and 23.5 months for regional lymph node and cutaneous metastases, respectively, vs. 31.4 months for distant metastases). Patients with metastases despite negative $S N B$ had a greater tumor thickness $(p=0.001)$, a higher rate of nodular melanoma $(p=0.001)$, ulceration $(p<0.001)$, and were older $(p=0.05)$ compared to SNB-negative patients without subsequent metastases. Out of SNB-negative patients, 16\% developed metastases. Conclusion: Close clinical followup including sonography of the draining lymph node region is mandatory for melanoma patients regardless of SNB status.
\end{abstract}

In Western countries, melanoma is one of the most common types of solid cancer (1). Approximately 20,000 new

Correspondence to: Dr. med. Michael Erdmann, MD, FriedrichAlexander-University Erlangen-Nürnberg (FAU), Department of Dermatology, Universitätsklinikum Erlangen, Ulmenweg 18, D91054 Erlangen, Germany. Tel: +49 091318535000, e-mail: michael.erdmann@uk-erlangen.de

Key Words: Cancer, melanoma, prognostic markers, lymphadenectomy, sentinel lymph node biopsy. melanoma cases are diagnosed every year in Germany, leading to 3,000 associated deaths per year (2).

Prognosis of melanoma patients is known to correlate with features such as tumor thickness, histological subtype and ulceration of the primary tumor (3). Melanoma metastasizes most commonly via lymphatic routes (4), and a tumor thickness of at least $1.0 \mathrm{~mm}$ increases the risk of lymphatic metastasis significantly (5). Thus, the status of the sentinel lymph node (SN) is considered a strong prognostic factor in melanoma patients and was included in the staging system for melanoma by the American Joint Committee on Cancer (6-8). Since then, SN biopsy (SNB) has become a standard procedure (9). The clinical benefit of SNB remains controversial, as improvement in overall survival by complete lymph node dissection in SNB-positive patients failed to be demonstrated in two phase III trials $(10,11)$, and the potential clinical benefit of SNB alone remains unproven (12). Histopathological SNB status, however, proved essential for refined staging and prognostication $(3,13,14)$.

The current German guideline recommends SNB in patients with melanoma with a tumor thickness of at least $1.0 \mathrm{~mm}$, or of $0.8 \mathrm{~mm}$ if additional risk factors such as ulceration, dermal mitoses or young patient age ( $<40$ years) are present (15). Especially after approval of novel adjuvant therapies for stage III melanoma (16-18), SNB status is also required for clinical decision making.

A positive $\mathrm{SN}$ is associated with an increased risk of further metastases $(14,19)$. However, up to $21.0 \%$ of patients with a negative SN can still develop metastases in the draining lymph node region in due course (20). In such a case, the SNB is discussed as being a false-negative (20). Reasons for falsenegative SNB include biological factors (e.g. tumor-or patientspecific) as well as technical factors (e.g. accuracy of nuclear medicine techniques, surgery, histopathology), which have been discussed in the literature (20).

The aim of this retrospective study was to analyze risk factors for regional and distant metastases in patients with 
SNB-negative melanoma. Therefore, data from 545 patients with melanoma who underwent SNB between August 2005 and December 2013 and subsequent follow-up at our hospital until December 2016 were evaluated. Different patient groups who underwent SNB with regard to tumor thickness, ulceration, histological subtype, localization, gender, and age were compared and these risk factors for SNB-negative patients developing metastases were analyzed.

\section{Patients and Methods}

A total of 574 patients with primary cutaneous melanoma between August 2005 and December 2013 were retrospectively analyzed. All patients underwent wide excision of the primary tumor and were planned for SNB at the Department of Surgery, University Hospital Erlangen, Erlangen, Germany. In 29 patients, it was not possible to detect the SN due to various causes. Therefore, these patients were excluded from the final analysis. Thus, the patient collective for further analysis with histologically examined SNB included 545 patients.

Patient data. Data on patient demographics (gender, age), primary tumor characteristics (location, histologicaI features: melanoma subtype, tumor thickness, ulceration), the surgical treatment (excision of the primary tumor, SNB), and date and kind of recurrence of melanoma were obtained for each patient. The location of the primary melanoma was classified into three anatomical sites: head/neck, trunk, and extremities. The histological subtype was classified into five categories: acral lentiginous melanoma, superficial spreading melanoma, nodular melanoma, lentigo maligna melanoma, and other. Histological tumor thickness was determined in all cases. Metastases were classified as regional lymph node/locoregional cutaneous metastases and distant metastases.

Clinical follow-up. Clinical follow-up of patients was performed according to the recommendations of the German Society of Dermatology (15) at the Department of Dermatology, University Hospital Erlangen, Germany including full-body skin examination, sonography of the regional draining lymph node region, and control of the serum tumor markers melanoma-inhibitory activity (MIA) and S100 (21). Clinical follow-up was performed until December 2016. SNB-negative patients who developed a recurrence within the local lymphatic draining basin of the melanoma were defined as patients with false-negative SNB.

Study groups and statistical analysis. This study compared the following groups: (i) SNB-negative patients who developed metastases $v s$. SNB-negative patients who did not develop metastases in the clinical follow-up; (ii) SNB-negative patients who developed primary locoregional nodal/cutaneous metastases during clinical follow-up vs. SNB-negative patients who developed primary distant metastases; (iii) SNB-negative patients who developed primary locoregional nodal/cutaneous metastases and subsequent distant metastases in clinical follow-up $v s$. SNB-negative patients who developed primary distant metastases without prior regional nodal/cutaneous metastases; and (iv) SNB-positive patients vs. patients with false-negative SNB.

Statistical analysis was performed using SPSS 23.0 for Microsoft Windows (IBM, Germany, Ehningen). All $p$-values were considered significant at 0.05 or less. Tables and figures were generated via Microsoft Excel 2016 (Microsoft, Redmond, Washington, USA).

\section{Results}

A total of 545 patients underwent SNB. SN was negative in 449 patients $(82.4 \%$, SNB-negative patients) whereas metastases in the $\mathrm{SN}$ were detected in 96 patients $(17.6 \%$, SNB-positive patients). During clinical follow-up of a median of 55 months, $72(16.0 \%)$ out of the 449 patients with negative SN developed locoregional and distant metastases (Figure 1). Twenty-five $(34.7 \%)$ out of these 72 patients developed primary distant metastases and 47 (63.3\%) primary locoregional nodal/cutaneous metastases. Of the latter, 22 patients developed subsequent distant metastases in due course.

SNB-negative patients who developed metastases in clinical follow-up vs. SNB-negative patients who did not. Seventytwo patients $(16.0 \%)$ out of 449 patients with a negative SNB developed metastases during clinical follow-up. SNBnegative patients who developed metastases in due course were significantly older $(p=0.05)$ and had a significantly greater tumor thickness $(p=0.001)$ when compared to SNBnegative patients who did not develop metastases in due course. In addition, more of these patients suffered from nodular melanoma $(p=0.001)$ and showed ulceration of the primary tumor $(p<0.001)$ (Table I). The results confirm that these factors are associated with metastasis development, even if the SNB is negative.

SNB-negative patients who developed primary locoregional nodal/cutaneous metastases in clinical follow-up vs. SNBnegative patients who developed primary distant metastases. Of the 72 SNB-negative patients, 25 developed primary nodal metastases in the draining lymph node region (34.7\%), 22 developed primary cutaneous satellite/in-transit metastases $(30.6 \%)$, and 25 developed primary distant metastases $(34.7 \%)$, as shown in Figure 1. Analysis of these three subgroups showed that initial locoregional metastases were more frequently seen in patients with melanoma of the extremities, whereas distant metastases were more frequently seen in patients with melanoma of the trunk $(p=0.03)$. Further clinicopathological parameters, e.g. gender, age, histological subtype, tumor thickness, and ulceration of the primary tumor did not significantly differ in our subgroups (Table II). Whereas locoregional nodal or cutaneous metastases occurred approximately 24.2 or 23.5 months after melanoma diagnosis, respectively, distant metastases were observed after approximately a mean of 31.1 months.

SNB-negative patients who developed primary locoregional nodal/cutaneous metastases and subsequent distant metastases in clinical follow-up vs. SNB-negative patients who developed primary distant metastases without prior locoregional nodal/cutaneous metastases. In clinical follow- 


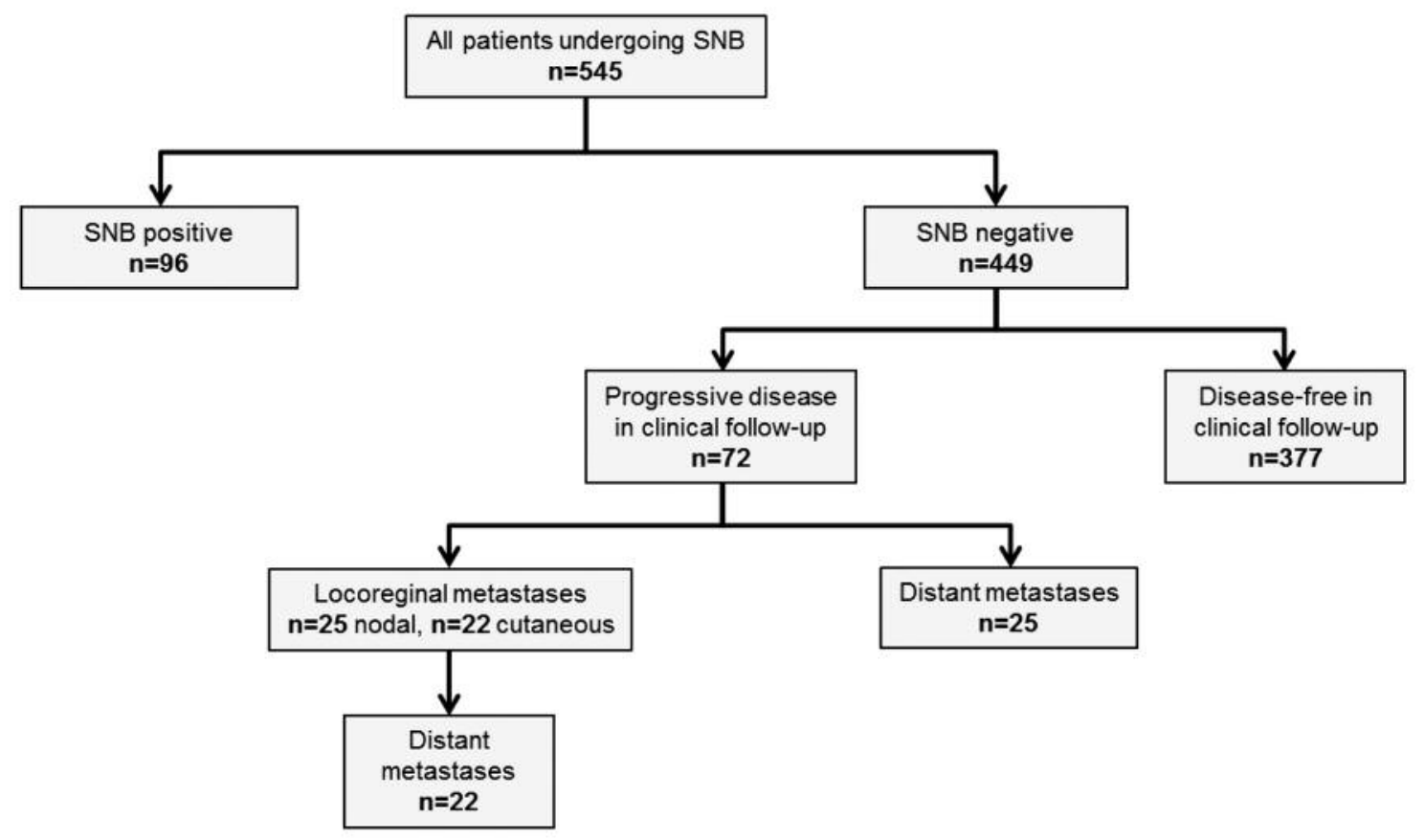

Figure 1. Overview of the whole study database (n=545). SNB: Sentinel lymph node biopsy.

up, some patients also developed primary locoregional metastases and subsequent distal metastases. Thus, we stratified these 72 patients with metastases after negative SNB into three groups: (i) patients with primary locoregional (nodal/cutaneous) metastases; (ii) patients with primary locoregional (nodal/cutaneous) and subsequent distant metastases; and (iii) patients with primary distant metastases (Table III). Although not statistically significant, more SNBnegative patients with subsequent distant metastases were male, had a thicker primary tumor and a higher rate of ulcerated primary tumor (Table III) compared to patients with locoregional but no subsequent distant metastases.

SNB-positive patients vs. patients with false-negative SNB. Nodal recurrence after negative SNB in the same nodal basin is considered a false-negative SNB. Biological factors of the tumor, as well as technical aspects of the SNB procedure, are considered to be possible causes. In our study, 25 patients (5.6\% of all SNB-negative patients) developed nodal metastases after negative SNB and thus had false-negative results. These 25 patients were compared to patients with positive SNB ( $n=96)$. Patients with false-negative SNB were significantly older $(p=0.01)$ and more often had a melanoma of the extremities $(p<0.001)$ when compared to patients with positive SNB (Table IV). We observed no significant differences concerning gender, histological subtype, tumor thickness, and ulceration.
Table I. Characteristics of patients with primary cutaneous melanoma with negative sentinel lymph node biopsy (SNB) who developed metastases in clinical follow-up (n=72) compared to SNB-negative patients who did not develop metastases $(n=377)$ with respect to prognostic factors.

\begin{tabular}{lccc}
\hline Characteristic & $\begin{array}{c}\text { Disease-free } \\
\text { during follow-up } \\
(\mathrm{n}=377)\end{array}$ & $\begin{array}{c}\text { Metastases } \\
\text { during follow-up } \\
(\mathrm{n}=72)\end{array}$ & $p$-Value \\
\hline Gender & & & \\
Male & $53.6 \%(\mathrm{n}=202)$ & $51.4 \%(\mathrm{n}=37)$ & 0.7 \\
Female & $46.4 \%(\mathrm{n}=175)$ & $48.6 \%(\mathrm{n}=35)$ & \\
Age (years $)$ & & & \\
Mean & $63.2 \pm 0.9$ & $68.1 \pm 1.5$ & 0.05 \\
$\quad$ Min/max & $20-96$ & $31-90$ & \\
Histological subtype & & & \\
ALM & $5.0 \%(\mathrm{n}=19)$ & $11.1 \%(\mathrm{n}=8)$ & 0.001 \\
LMM & $1.9 \%(\mathrm{n}=7)$ & $0.0 \%(\mathrm{n}=0)$ & \\
NM & $44.0 \%(\mathrm{n}=166)$ & $61.1 \%(\mathrm{n}=44)$ & \\
SSM & $38.5 \%(\mathrm{n}=145)$ & $27.8 \%(\mathrm{n}=20)$ & \\
Other & $10.6 \%(\mathrm{n}=40)$ & $27.8 \%(\mathrm{n}=20)$ & \\
Thickness (mm) & & & \\
$\quad$ Mean & $2.2 \pm 0.1$ & $4.0 \pm 0.5$ & 0.001 \\
Ulceration & & & \\
$\quad$ Yes & $24.7 \%(\mathrm{n}=93)$ & $47.2 \%(\mathrm{n}=34)$ & $<0.001$ \\
$\quad$ No & $75.3 \%(\mathrm{n}=284)$ & $52.8 \%(\mathrm{n}=38)$ & \\
Localization & & & \\
$\quad$ Head/neck & $8.2 \%(\mathrm{n}=31)$ & $13.9 \%(\mathrm{n}=10)$ & 0.1 \\
Trunk & $31.3 \%(\mathrm{n}=118)$ & $22.2 \%(\mathrm{n}=16)$ & \\
Extremities & $60.5 \%(\mathrm{n}=228)$ & $63.9 \%(\mathrm{n}=46)$ & \\
\hline & & & \\
\hline
\end{tabular}

ALM: Acral lentiginous melanoma; LMM: lentigo maligna melanoma; NM: nodular melanoma; SSM: superficial spreading melanoma. 
Table II. Characteristics of patients with primary cutaneous melanoma with negative sentinel lymph node biopsy (SNB) who developed primary regional nodal metastases in clinical follow-up $(n=25)$ compared to $S N B$-negative patients who developed primary regional cutaneous satellite/in-transit metastases $(n=22)$ and primary distant metastases $(n=25)$ with respect to prognostic factors.

\begin{tabular}{|c|c|c|c|}
\hline Characteristic & $\begin{array}{c}\text { Regional nodal } \\
\text { metastases } \\
(\mathrm{n}=25)\end{array}$ & $\begin{array}{c}\text { Regional } \\
\text { skin metastases } \\
\quad(n=22)\end{array}$ & $\begin{array}{l}\text { Primary distant } \\
\text { metastases } \\
(\mathrm{n}=25)\end{array}$ \\
\hline \multicolumn{4}{|l|}{ Gender } \\
\hline Male & $52.0 \%(\mathrm{n}=13)$ & $54.5(\mathrm{n}=12)$ & $48.0 \%(n=12)$ \\
\hline Female & $48.0 \%(n=12)$ & $45.5 \%(\mathrm{n}=10)$ & $52.0 \%(\mathrm{n}=13)$ \\
\hline \multicolumn{4}{|l|}{ Age (years) } \\
\hline Mean & $69.9 \pm 2.4$ & $67.2 \pm 2.6$ & $67 \pm 2.7$ \\
\hline $\operatorname{Min} / \max$ & $45 / 86$ & $44 / 90$ & $31 / 84$ \\
\hline \multicolumn{4}{|c|}{ Histological subtype } \\
\hline ALM & $24 \%(n=6)$ & $4.5 \%(n=1)$ & $4 \%(n=1)$ \\
\hline LMM & $0.0 \%(\mathrm{n}=0)$ & $0.0 \%(\mathrm{n}=0)$ & $0.0 \%(\mathrm{n}=0)$ \\
\hline NM & $48 \%(n=12)$ & $68.1 \%(n=15)$ & $68 \%(n=17)$ \\
\hline SSM & $16.0 \%(n=4)$ & $9.1 \%(n=2)$ & $16.0 \%(n=4)$ \\
\hline UCM & $12.0 \%(\mathrm{n}=3)$ & $18.2 \%(n=4)$ & $12.0 \%(\mathrm{n}=3)$ \\
\hline \multicolumn{4}{|l|}{ Thickness (mm) } \\
\hline Mean & $3.7 \pm 0.4$ & $3.5 \pm 0.8$ & $4.6 \pm 1$ \\
\hline \multicolumn{4}{|l|}{ Ulceration } \\
\hline Yes & $48.0 \%(\mathrm{n}=12)$ & $45.5 \%(\mathrm{n}=10)$ & $48.0 \%(n=12)$ \\
\hline No & $52.0 \%(\mathrm{n}=13)$ & $54.5 \%(\mathrm{n}=12)$ & $52.0 \%(\mathrm{n}=13)$ \\
\hline \multicolumn{4}{|l|}{ Localization } \\
\hline Head/neck & $8.0 \%(n=2)$ & $22.7 \%(n=5)$ & $12.0 \%(n=3)$ \\
\hline Trunk & $12.0 \%(\mathrm{n}=3)$ & $13.6 \%(\mathrm{n}=3)$ & $40.0 \%(n=10)$ \\
\hline Extremities & $80.0 \%(n=20)$ & $63.6 \%(n=14)$ & $48.0 \%(n=12)$ \\
\hline \multicolumn{4}{|c|}{$\begin{array}{l}\text { Time until } \\
\text { progression (months) }\end{array}$} \\
\hline Mean & 24.2 & 23.5 & 31.1 \\
\hline $\operatorname{Min} / \max$ & $8 / 59$ & $3 / 129$ & $1 / 96$ \\
\hline
\end{tabular}

ALM: Acral lentiginous melanoma; LMM: lentigo maligna melanoma; NM: nodular melanoma; SSM: superficial spreading melanoma.

\section{Discussion}

SNB is the standard of care in cutaneous melanoma which has a tumor thickness of at least $1.0 \mathrm{~mm}$, or of $0.8 \mathrm{~mm}$ with additional risk factors (15). In melanoma with a tumor thickness of 1.0-4.0 mm, metastases in the $\mathrm{SN}$ are present in $25 \%$ of patients (3) which our data are in good accordance with as there were $17.6 \%$ SNB-positive patients ( $\mathrm{n}=96$, out of a total of 545 patients). As reported in the literature (2), tumor thickness and ulceration of the primary tumor are risk factors for positive SNB. Male gender as an independent risk factor as observed in our patient collective was also described in some prior studies $(14,22)$.

A negative SNB is known to be associated with a beneficial prognosis in medium- to high-risk melanoma (23). However, $16.0 \%$ of our patients ( $\mathrm{n}=72$, out of a total of 449 patients) still developed regional $(n=25)$ or distant $(n=47)$ metastases during
Table III. Characteristics of patients with primary cutaneous melanoma with negative sentinel lymph node biopsy (SNB) who developed primary regional nodal/cutaneous metastases in clinical follow-up (n=22) compared to SNB-negative patients who developed primary regional and subsequent distant metastases $(n=25)$ and primary distant metastases $(n=25)$ with respect to prognostic factors.

\begin{tabular}{|c|c|c|c|}
\hline Characteristic & $\begin{array}{c}\text { Primary } \\
\text { regional } \\
\text { metastases } \\
(\mathrm{n}=22)\end{array}$ & $\begin{array}{c}\text { Primary } \\
\text { regional } \\
\text { and subsequent } \\
\text { distant metastases } \\
(\mathrm{n}=25)\end{array}$ & $\begin{array}{c}\text { Primary } \\
\text { distant } \\
\text { metastases } \\
(n=25)\end{array}$ \\
\hline \multicolumn{4}{|l|}{ Gender } \\
\hline Male & $45.2 \%(n=14)$ & $63.6 \%(\mathrm{n}=14)$ & $48.0 \%(\mathrm{n}=12)$ \\
\hline Female & $54.8 \%(\mathrm{n}=17)$ & $36.4 \%(n=8)$ & $52.0 \%(\mathrm{n}=13)$ \\
\hline \multicolumn{4}{|l|}{ Age (years) } \\
\hline Mean & $66.7 \pm 2.6$ & $68.5 \pm 2.4$ & $67.0 \pm 2.7$ \\
\hline $\operatorname{Min} / \max$ & $32-90$ & $49-85$ & $31-84$ \\
\hline \multicolumn{4}{|c|}{ Histological subtype } \\
\hline ALM & $12.9 \%(n=4)$ & $13.6 \%(n=3)$ & $4.0 \%(\mathrm{n}=1)$ \\
\hline LMM & $0.0 \%(\mathrm{n}=0)$ & $0.0 \%(\mathrm{n}=0)$ & $0.0 \%(\mathrm{n}=0)$ \\
\hline NM & $54.8 \%(\mathrm{n}=17)$ & $63.6 \%(\mathrm{n}=14)$ & $68.0 \%(n=17)$ \\
\hline SSM & $16.1 \%(\mathrm{n}=5)$ & $13.6 \%(n=3)$ & $16.0 \%(n=4)$ \\
\hline UCM & $16.1 \%(n=5)$ & $9.1 \%(n=2)$ & $12.0 \%(\mathrm{n}=3)$ \\
\hline \multicolumn{4}{|c|}{ Thickness (mm) } \\
\hline Mean & $2.8 \pm 0.3$ & $4.4 \pm 0.9$ & $4.6 \pm 1.0$ \\
\hline \multicolumn{4}{|l|}{ Ulceration } \\
\hline Yes & $35.5 \%(n=11)$ & $54.5 \%(\mathrm{n}=12)$ & $48.0 \%(n=12)$ \\
\hline No & $64.5 \%(n=20)$ & $45.5 \%(\mathrm{n}=10)$ & $52.0 \%(n=13)$ \\
\hline \multicolumn{4}{|l|}{ Localization } \\
\hline Head/neck & $12.9 \%(n=4)$ & $18.2 \%(n=4)$ & $12.0 \%(\mathrm{n}=3)$ \\
\hline Trunk & $9.7 \%(\mathrm{n}=3)$ & $13.6 \%(n=3)$ & $40.0 \%(n=10)$ \\
\hline Extremities & $77.4 \%(n=24)$ & $68.2 \%(\mathrm{n}=15)$ & $48.0 \%(n=12)$ \\
\hline \multicolumn{4}{|c|}{$\begin{array}{l}\text { Time until } \\
\text { progression (month) }\end{array}$} \\
\hline \multicolumn{4}{|c|}{ Regional } \\
\hline Mean & 21.9 & 13.6 & \\
\hline $\operatorname{Min} / \max$ & $1 / 61$ & $1 / 19$ & \\
\hline \multicolumn{4}{|l|}{ Systemic } \\
\hline Mean & & 29.5 & 31.1 \\
\hline $\operatorname{Min} / \max$ & & $9 / 64$ & $1 / 96$ \\
\hline
\end{tabular}

ALM: Acral lentiginous melanoma; LMM: lentigo maligna melanoma, NM: nodular melanoma; SSM: superficial spreading melanoma.

clinical follow-up, despite having a negative SNB. This result is within the range of $5.6-21.0 \%$ which was reported in the literature (20). The variation of recurrences is dependent on the follow-up interval. Kretschmer et al. reported an increase in nodal basin recurrences of SNB-negative patients of $2.5 \%$ (after 1-year follow-up) up to $12.6 \%$ (after 10 years of followup) in 2,653 patients (24). We, therefore, included patients at our hospital from 2005-2013 to ensure a sufficiently long follow-up interval with a mean of at least 3 years.

Our data confirm the nodular melanoma subtype, greater tumor thickness, as well as ulceration of the primary tumor as risk factors for future metastases after negative SNB (7, 25-27). Nodular melanoma compared to superficial 
Table IV. Characteristics of patients with primary cutaneous melanoma with positive sentinel lymph node biopsy (SNB) compared to patients with false-negative $S N B$ with respect to prognostic factors.

\begin{tabular}{lccc}
\hline & FN SNB $(\mathrm{n}=25)$ & SNB pos $(\mathrm{n}=96)$ & $p$-Value \\
\hline Gender & & & \\
Male & $52.0 \%(\mathrm{n}=13)$ & $69.8 \%(\mathrm{n}=67)$ & 0.09 \\
Female & $48.0 \%(\mathrm{n}=12)$ & $30,2 \%(\mathrm{n}=29)$ & \\
Age (years) & & & \\
$\quad$ Mean & $69.9 \pm 2.4$ & $62.4 \pm 1.7$ & \\
Min/max & $45 / 86$ & $20 / 90$ & 0.01 \\
Histological subtype & & & \\
ALM & $24.0 \%(\mathrm{n}=6)$ & $8.3 \%(\mathrm{n}=8)$ & 0.2 \\
LMM & $0.0(\mathrm{n}=0)$ & $0.0(\mathrm{n}=0)$ & \\
NM & $48.0 \%(\mathrm{n}=12)$ & $65.6 \%(\mathrm{n}=63)$ & \\
SSM & $16.0 \%(\mathrm{n}=4)$ & $18.8 \%(\mathrm{n}=18)$ & \\
UCM & $12.0 \%(\mathrm{n}=3)$ & $7.3 \%(\mathrm{n}=7)$ & \\
Thickness $(\mathrm{mm})$ & & & \\
Mean $(\mathrm{mm})$ & $3.7 \pm 0.4$ & $4.3 \pm 0.32$ & 0.4 \\
Ulceration & & & \\
Yes & $48.0 \%(\mathrm{n}=12)$ & $49.0 \%(\mathrm{n}=47)$ & 0.93 \\
No & $52.0 \%(\mathrm{n}=13)$ & $51.0 \%(\mathrm{n}=49)$ & \\
Localization & & & \\
Head/neck & $8.0 \%(\mathrm{n}=2)$ & $9.4 \%(\mathrm{n}=9)$ & $<0.001$ \\
Trunk & $12.0 \%(\mathrm{n}=3)$ & $44.8 \%(\mathrm{n}=43)$ & \\
Extremities & $80.0 \%(\mathrm{n}=20)$ & $45.8 \%(\mathrm{n}=44)$ & \\
\hline
\end{tabular}

SNB: Sentinel lymph node biopsy; FN: false-negative; pos: positive; ALM: acral lentiginous melanoma; LMM: lentigo maligna melanoma; NM: nodular melanoma; SSM: superficial spreading melanoma.

spreading melanoma in 214 consecutive patients was, for instance, associated with a higher tumor thickness as well as a higher ulceration rate, but not with a mandatory risk of recurrence (28). This co-dependence of melanoma subtype, tumor thickness, and ulceration has to be considered, as well as the size of the patient cohorts of these studies.

We stratified our 72 patients with melanoma metastases after negative SNB into three groups for detailed analysis. Twenty-five of these patients developed primary regional nodal metastases in clinical follow-up (34.7\%), 22 patients developed regional cutaneous satellite/in-transit metastases (30.6\%), and 25 developed primary distant metastases $(34.7 \%)$. This distribution in our study differs from reports in the literature, where the majority of patients either developed regional cutaneous satellite/in-transit metastases (22) or distant metastases (27). Regarding the time interval until disease progression, our patients developed regional metastases after a mean of 24 months, whereas primary and secondary distant metastases were seen at significantly later time-points of 31 and 29 months, respectively. Jones et al. described comparable time intervals until disease progression with locoregional cutaneous (23 months) as well as distant metastases (30 months), whereas locoregional nodal metastases were already seen after approximately 14 months.
In order to perform the surgical procedure for SNB, collaboration of different medical specialties is necessary, including i) nuclear medicine for correct injection of the tracer (29) and imaging technique for localization of the SNB (30); ii) surgery with a standardized technique to define an intraoperative successful excision of the SNB; and iii) pathology with serial tissue sectioning and immunohistochemistry (15), as well as additional molecularpathological techniques $(31,32)$. Intrinsic reasons for regional recurrence of melanoma despite a negative SNB include the biology of melanoma with lymphovascular invasion and local/in-transit recurrences (33). Moreover, patient-specific factors such as variability in the lymphatic drainage, especially observed in the head/neck region $(22,34)$, as well as lymphatic dysfunction in the elderly (35), and lymphatic obstruction (36) have been described. In our study, patients with false-negative SNB were significantly older than patients with positive SNB, representing a possible dysfunction of lymphatic drainage with progressive age. Our data confirm risk factors for recurrence after negative SNB such as older age, tumor thickness, and ulceration.

In summary, the current study of cutaneous melanomas demonstrated that tumor thickness, ulceration, nodular melanoma, as well as age, are significant risk factors for developing locoregional nodal/cutaneous as well as distant metastases in patients with melanoma with negative SNB. Furthermore, in patients with primary loco-regional recurrence within a short time interval after SNB, a high risk for further systemic metastases exists. Thus, close clinical follow-up including sonography of the regional draining lymph node region, as well as radiological examinations, is mandatory in patients with the presented risk factors. Interestingly, especially in older patients with negative SNB, there is an increased risk for false-negative results. Therefore, these patients need a close follow-up.

\section{References}

1 Schadendorf D, Fisher DE, Garbe C, Gershenwald JE, Grob JJ, Halpern A, Herlyn M, Marchetti MA, McArthur G, Ribas A, Roesch A and Hauschild A: Melanoma. Nat Rev Dis Primers 1: 15003, 2015.

2 Robert-Koch-Institut: Krebs in Deutschland fur 2013/2014. Berlin: Robert-Koch-Institut und Gesellschaft der epidemiologischen Krebsregister in Deutschland e.V., 2017.

3 Balch CM, Gershenwald JE, Soong SJ, Thompson JF, Atkins MB, Byrd DR, Buzaid AC, Cochran AJ, Coit DG, Ding S, Eggermont AM, Flaherty KT, Gimotty PA, Kirkwood JM, McMasters KM, Mihm MC Jr., Morton DL, Ross MI, Sober AJ and Sondak VK: Final version of 2009 AJCC melanoma staging and classification. J Clin Oncol 27: 6199-6206, 2009.

4 Emmett MS, Symonds KE, Rigby H, Cook MG, Price R, Metcalfe C, Orlando A and Bates DO: Prediction of melanoma metastasis by the Shields index based on lymphatic vessel density. BMC Cancer 10: 208, 2010. 
5 Buettner P, Garbe C and Guggenmoos-Holzmann I: Problems in defining cutoff points of continuous prognostic factors: example of tumor thickness in primary cutaneous melanoma. J Clin Epidemiol 50: 1201-1210, 1997.

6 Kettlewell S, Moyes C, Bray C, Soutar D, MacKay A, Byrne D, Shoaib T, Majumder B and MacKie R: Value of sentinel node status as a prognostic factor in melanoma: prospective observational study. BMJ 332: 1423, 2006.

7 Yee VS, Thompson JF, McKinnon JG, Scolyer RA, Li LX, McCarthy WH, O'Brien CJ, Quinn MJ, Saw RP, Shannon KF, Stretch JR and Uren RF: Outcome in 846 cutaneous melanoma patients from a single center after a negative sentinel node biopsy. Ann Surg Oncol 12: 429-439, 2005.

8 Leiter U, Buettner PG, Bohnenberger K, Eigentler T, Meier F, Moehrle M, Breuninger $\mathrm{H}$ and Garbe C: Sentinel lymph node dissection in primary melanoma reduces subsequent regional lymph node metastasis as well as distant metastasis after nodal involvement. Ann Surg Oncol 17: 129-137, 2010.

9 Morton DL, Thompson JF, Cochran AJ, Mozzillo N, Elashoff R, Essner R, Nieweg OE, Roses DF, Hoekstra HJ, Karakousis CP, Reintgen DS, Coventry BJ, Glass EC and Wang HJ: Sentinelnode biopsy or nodal observation in melanoma. N Engl J Med 355: 1307-1317, 2006.

10 Leiter U, Stadler R, Mauch C, Hohenberger W, Brockmeyer N, Berking C, Sunderkotter C, Kaatz M, Schulte KW, Lehmann P, Vogt T, Ulrich J, Herbst R, Gehring W, Simon JC, Keim U, Martus $\mathrm{P}$ and Garbe $\mathrm{C}$ : Complete lymph node dissection versus no dissection in patients with sentinel lymph node biopsy positive melanoma (DeCOG-SLT): A multicentre, randomised, phase 3 trial. Lancet Oncol 17: 757-767, 2016.

11 Faries MB, Thompson JF, Cochran AJ, Andtbacka RH, Mozzillo N, Zager JS, Jahkola T, Bowles TL, Testori A, Beitsch PD, Hoekstra HJ, Moncrieff M, Ingvar C, Wouters M, Sabel MS, Levine EA, Agnese D, Henderson M, Dummer R, Rossi CR, Neves RI, Trocha SD, Wright F, Byrd DR, Matter M, Hsueh E, MacKenzie-Ross A, Johnson DB, Terheyden P, Berger AC, Huston TL, Wayne JD, Smithers BM, Neuman HB, Schneebaum S, Gershenwald JE, Ariyan CE, Desai DC, Jacobs L, McMasters KM, Gesierich A, Hersey P, Bines SD, Kane JM, Barth RJ, McKinnon G, Farma JM, Schultz E, Vidal-Sicart S, Hoefer RA, Lewis JM, Scheri R, Kelley MC, Nieweg OE, Noyes RD, Hoon DSB, Wang HJ, Elashoff DA and Elashoff RM: Completion dissection or observation for sentinel-node metastasis in melanoma. N Engl J Med 376: 2211-2222, 2017.

12 Morton DL, Thompson JF, Cochran AJ, Mozzillo N, Nieweg OE, Roses DF, Hoekstra HJ, Karakousis CP, Puleo CA, Coventry BJ, Kashani-Sabet M, Smithers BM, Paul E, Kraybill WG, McKinnon JG, Wang HJ, Elashoff R and Faries MB: Final trial report of sentinel-node biopsy versus nodal observation in melanoma. N Engl J Med 370: 599-609, 2014.

13 Balch CM, Soong SJ, Atkins MB, Buzaid AC, Cascinelli N, Coit DG, Fleming ID, Gershenwald JE, Houghton A Jr., Kirkwood JM, McMasters KM, Mihm MF, Morton DL, Reintgen DS, Ross MI, Sober A, Thompson JA and Thompson JF: An evidencebased staging system for cutaneous melanoma. CA Cancer J Clin 54: 131-149, 2004.

14 Uslu U, Schuler G and Breuninger H: Factors influencing disease progression in patients with head and neck melanoma. Anticancer Res 37: 3811-3816, 2017.
15 Pflugfelder A, Kochs C, Blum A, Capellaro M, Czeschik C, Dettenborn T, Dill D, Dippel E, Eigentler T, Feyer P, Follmann M, Frerich B, Ganten MK, Gartner J, Gutzmer R, Hassel J, Hauschild A, Hohenberger P, Hubner J, Kaatz M, Kleeberg UR, Kolbl O, Kortmann RD, Krause-Bergmann A, Kurschat P, Leiter U, Link H, Loquai C, Loser C, Mackensen A, Meier F, Mohr P, Mohrle M, Nashan D, Reske S, Rose C, Sander C, Satzger I, Schiller M, Schlemmer HP, Strittmatter G, Sunderkotter C, Swoboda L, Trefzer U, Voltz R, Vordermark D, Weichenthal M, Werner A, Wesselmann S, Weyergraf AJ, Wick W, Garbe C and Schadendorf D: Malignant melanoma S3-guideline "Diagnosis, Therapy and Follow-up of Melanoma". J Dtsch Dermatol Ges 11(Suppl 6): 1-116, 111-126, 2013.

16 Eggermont AMM, Blank CU, Mandala M, Long GV, Atkinson V, Dalle S, Haydon A, Lichinitser M, Khattak A, Carlino MS, Sandhu S, Larkin J, Puig S, Ascierto PA, Rutkowski P, Schadendorf D, Koornstra R, Hernandez-Aya L, Maio M, van den Eertwegh AJM, Grob JJ, Gutzmer R, Jamal R, Lorigan P, Ibrahim N, Marreaud S, van Akkooi ACJ, Suciu $\mathrm{S}$ and Robert C: Adjuvant pembrolizumab versus placebo in resected stage III melanoma. N Engl J Med 378: 1789-1801, 2018.

17 Long GV, Hauschild A, Santinami M, Atkinson V, Mandala M, Chiarion-Sileni V, Larkin J, Nyakas M, Dutriaux C, Haydon A, Robert C, Mortier L, Schachter J, Schadendorf D, Lesimple T, Plummer R, Ji R, Zhang P, Mookerjee B, Legos J, Kefford R, Dummer $\mathrm{R}$ and Kirkwood JM: Adjuvant dabrafenib plus trametinib in stage III BRAF-mutated melanoma. N Engl J Med 377: 1813-1823, 2017.

18 Weber J, Mandala M, Del Vecchio M, Gogas HJ, Arance AM, Cowey CL, Dalle S, Schenker M, Chiarion-Sileni V, MarquezRodas I, Grob JJ, Butler MO, Middleton MR, Maio M, Atkinson V, Queirolo P, Gonzalez R, Kudchadkar RR, Smylie M, Meyer $\mathrm{N}$, Mortier L, Atkins MB, Long GV, Bhatia S, Lebbe C, Rutkowski P, Yokota K, Yamazaki N, Kim TM, de Pril V, Sabater J, Qureshi A, Larkin J, Ascierto PA and CheckMate C: Adjuvant nivolumab versus ipilimumab in resected stage III or IV melanoma. N Engl J Med 377: 1824-1835, 2017.

19 Gershenwald JE, Scolyer RA, Hess KR, Sondak VK, Long GV, Ross MI, Lazar AJ, Faries MB, Kirkwood JM, McArthur GA, Haydu LE, Eggermont AMM, Flaherty KT, Balch CM and Thompson JF: Melanoma staging: Evidence-based changes in the American Joint Committee on Cancer Eighth Edition Cancer Staging Manual. CA Cancer J Clin 67: 472492, 2017.

20 Manca G, Rubello D, Romanini A and Mariani G: False-negative sentinel lymph node biopsy in melanoma patients. Nucl Med Commun 35: 989-994, 2014.

21 Uslu U, Schliep S, Schliep K, Erdmann M, Koch HU, Parsch H, Rosenheinrich S, Anzengruber D, Bosserhoff AK, Schuler G and Schuler-Thurner B: Comparison of the serum tumor markers S100 and melanoma-inhibitory activity (MIA) in the monitoring of patients with metastatic melanoma receiving vaccination immunotherapy with dendritic cells. Anticancer Res 37: 50335037, 2017.

22 Jones EL, Jones TS, Pearlman NW, Gao D, Stovall R, Gajdos C, Kounalakis N, Gonzalez R, Lewis KD, Robinson WA and McCarter MD: Long-term follow-up and survival of patients following a recurrence of melanoma after a negative sentinel lymph node biopsy result. JAMA Surg 148: 456-461, 2013. 
23 Wong SL, Balch CM, Hurley P, Agarwala SS, Akhurst TJ, Cochran A, Cormier JN, Gorman M, Kim TY, McMasters KM, Noyes RD, Schuchter LM, Valsecchi ME, Weaver DL and Lyman GH: Sentinel lymph node biopsy for melanoma: American Society of Clinical Oncology and Society of Surgical Oncology joint clinical practice guideline. J Clin Oncol 30 : 2912-2918, 2012.

24 Kretschmer L, Bertsch HP, Zapf A, Mitteldorf C, Satzger I, Thoms KM, Volker B, Schon MP, Gutzmer R and Starz H: Nodal basin recurrence after sentinel lymph node biopsy for melanoma: A retrospective multicenter study in 2653 patients Medicine 94: e1433, 2015.

25 Nowecki ZI, Rutkowski P, Nasierowska-Guttmejer A and Ruka W: Survival analysis and clinicopathological factors associated with false-negative sentinel lymph node biopsy findings in patients with cutaneous melanoma. Ann Surg Oncol 13: 1655$1663,2006$.

26 O'Connell EP, O'Leary DP, Fogarty K, Khan ZJ and Redmond HP: Predictors and patterns of melanoma recurrence following a negative sentinel lymph node biopsy. Melanoma Res 26: 6670, 2016.

27 Faut M, Wevers KP, van Ginkel RJ, Diercks GF, Hoekstra HJ, Kruijff S, Been LB and van Leeuwen BL: Nodular histologic subtype and ulceration are tumor factors associated with high risk of recurrence in sentinel node-negative melanoma patients. Ann Surg Oncol 24: 142-149, 2017.

28 Pizzichetta MA, Massi D, Mandala M, Queirolo P, Stanganelli I, De Giorgi V, Ghigliotti G, Cavicchini S, Quaglino P, Corradin MT, Rubegni P, Alaibac M, Astorino S, Ayala F, Magi S, Mazzoni L, Manganoni MA, Talamini R, Serraino D and Palmieri G: Clinicopathological predictors of recurrence in nodular and superficial spreading cutaneous melanoma: a multivariate analysis of 214 cases. J Transl Med 15: 227, 2017.

29 Uren RF, Howman-Giles R, Chung DK, Morton RL and Thompson JF: The reproducibility in routine clinical practice of sentinel lymph node identification by pre-operative lymphoscintigraphy in patients with cutaneous melanoma. Ann Surg Oncol 14: 899-905, 2007.
30 Klode J, Poeppel T, Boy C, Mueller S, Schadendorf D, Korber A, Stoffels I and Dissemond J: Advantages of preoperative hybrid SPECT/CT in detection of sentinel lymph nodes in cutaneous head and neck malignancies. J Eur Acad Dermatol Venereol 25: 1213-1221, 2011.

31 Manca G, Romanini A, Rubello D, Mazzarri S, Boni G, Chiacchio S, Tredici M, Duce V, Tardelli E, Volterrani D and Mariani G: A critical reappraisal of false negative sentinel lymph node biopsy in melanoma. Q J Nucl Med Mol Imaging 58: 105113, 2014.

32 Eigentler TK, Hinderer J, Noor S, Garbe C and Leiter U: Prognostic impact of tumour burden measured by quantitative real-time PCR from sentinel lymph nodes of melanoma patients: data from 10-year follow-up. J Cancer Res Clin Oncol 143: 703$708,2017$.

33 Scoggins CR, Martin RC, Ross MI, Edwards MJ, Reintgen DS, Urist MM, Gershenwald JE, Sussman JJ, Dirk Noyes R, Goydos JS, Beitsch PD, Ariyan S, Stromberg AJ, Hagendoorn LJ and McMasters KM: Factors associated with false-negative sentinel lymph node biopsy in melanoma patients. Ann Surg Oncol 17: 709-717, 2010.

34 Hoetzenecker W, Guenova E, Bottinger TU, Hafner HM and Breuninger H: Mapping of specific sentinel node locations for skin cancer of the head. Eur J Dermatol 21: 354-358, 2011.

35 Conway WC, Faries MB, Nicholl MB, Terando AM, Glass EC, Sim M and Morton DL: Age-related lymphatic dysfunction in melanoma patients. Ann Surg Oncol 16: 1548-1552, 2009.

36 Leijte JA, van der Ploeg IM, Valdes Olmos RA, Nieweg OE and Horenblas S: Visualization of tumor blockage and rerouting of lymphatic drainage in penile cancer patients by use of SPECT/CT. J Nucl Med 50: 364-367, 2009.
Received October 1, 2018

Revised October 19, 2018 Accepted October 23, 2018 